\title{
Solar disinfection: an approach for low-cost household water treatment technology in Southwestern Ethiopia
}

\author{
Awrajaw Dessie ${ }^{1 *}$, Esayas Alemayehu ${ }^{2}$, Seblework Mekonen², Worku Legesse ${ }^{3}$, Helmut Kloos $^{4}$ and Argaw Ambelu²
}

\begin{abstract}
Disinfection of contaminated water using solar radiation (SODIS) is known to inactivate bacteria. Its inactivation efficiency depends on local conditions where the disinfection is made. This study was aiming to test the efficiency of solar disinfection using different water parameters as low-cost household water treatment technology. Inactivation of microbes was tested using fecal coliform as test organism. The SODIS experiment was carried out at turbidity $2 \mathrm{NTU}, \mathrm{pH} 7$, and various water temperature $\left(38.1^{\circ} \mathrm{C}, 41.8^{\circ} \mathrm{C}, 45.6^{\circ} \mathrm{Cand} 51.1^{\circ} \mathrm{C}\right)$ and solar intensities, using clear and black plastic bottles filled to different depths. The results show that the rate of microbial inactivation in relation to depth of water, turbidity, container type, intensity of light and color of container was statistically significant $(p<0.05)$. However, bottle placement, exposure and water $\mathrm{pH}$ were unrelated to microbial inactivation. Bacterial re-growth was not observed after solar disinfection. By adjusting the parameters, complete and irreversible fecal coliform inactivation was achieved within an exposure time of less than four hours in the areas where the solar irradiance is about $3.99 \mathrm{~kW} / \mathrm{m}^{2}$ and above. Our results indicate that application of SODIS could play a significant role in the provision of safe water in rural communities of developing countries where there is ample sunshine, specifically in sub-Saharan African countries.
\end{abstract}

Keywords: Safe water supply, Water disinfection, Household water treatment, Solar radiation

\section{Background}

Ethiopia and some other developing countries have large fresh water resources. However, those countries cannot cover the expense of constructing water and wastewater treatment plants, distribution systems and the cost of the treatment processes for all residents. Globally, over 1.1 billion people are at risk of becoming infected with water-related pathogens due to lack of access to safe drinking water [1], a problem that is also widespread in Ethiopia [2].

Conventional water treatment plants in Ethiopia are scarce and the existing plants are vulnerable to frequent interruption and technical malfunction. Expanding treatment plants in rural areas is difficult due to logistics and scarcity of chemicals, energy, and lack of know-how [3]. Commercially produced filters are relatively costly, and filters made of locally available material are generally of limited treatment efficiency in improving microbiological water quality [4].

Several studies indicated that solar disinfection may be an alternative, low- cost, effective and simple method of water purification for use at the household level [5-7]. However, additional studies under different local environmental conditions (solar intensity, temperatures, precipitation), are necessary because the disinfection potential of SODIS varies from place to place. Adequate databases of environmental conditions in a given area of SODIS application may permit the development of models that could be used to test optimum disinfection potential [5]. No database exists on environmental parameters in Ethiopia to carry out SODIS experiments using coliform or other water-related pathogens.

\footnotetext{
* Correspondence: awrajawdss@gmail.com

'Department of Public Health, College of Health Science, Mekelle University, Mekelle, Ethiopia

Full list of author information is available at the end of the article
}

\section{Biomed Central}

(c) 2014 Dessie et al.; licensee BioMed Central Ltd. This is an open access article distributed under the terms of the Creative Commons Attribution License (http://creativecommons.org/licenses/by/2.0), which permits unrestricted use, distribution, and reproduction in any medium, provided the original work is properly cited. 


\section{Methods}

\section{Laboratory tests}

A laboratory based experimental study was conducted in Jimma town, Ethiopia from April to June 7, 2011. Synthetic water deliberately contaminated with fecal matter was used as raw water.

Subsequently the efficiency of solar disinfection was evaluated using well water. The level of microbial inactivation was determined in the form of log inactivation following the method described below:

$\log$ inactivation $=\log 10 \mathrm{~N}_{\mathrm{t}} / \mathrm{N}_{0}$

Where, $\mathrm{N}_{\mathrm{t}}$ = count of microbes in CFU/mL at a time " $\mathrm{t}$ ". $\mathrm{N}_{0}=$ initial count of microbes in CFU/mL

First order inactivation rate constant (k) of fecal coliform was computed based on Chick's law [8] by performing linear regression analysis on plots of $\mathrm{Ln}\left(\mathrm{N} / \mathrm{N}_{0}\right)$ versus " $\mathrm{t}$ ".

\section{Testing the efficiency of SODIS under different parameters}

The efficiency of SODIS was tested under different levels of turbidity, water depths in bottles, water temperatures, and solar intensities. To determine the effect of raw water turbidity, raw water samples having turbidity levels of, 2, 13, 25, 46 and $81 \mathrm{NTU}$ were used. To determine the effect of water depth on SODIS, bottles having $0.5 \mathrm{~L}$ of $5.5 \mathrm{~cm}$ water depth, $1.0 \mathrm{~L}$ of $7.5 \mathrm{~cm}$ water depth, $1.5 \mathrm{~L}$ of $8.5 \mathrm{~cm}$ water depth and $2.0 \mathrm{~L}$ of $10 \mathrm{~cm}$ water depth were filled with raw water having initial bacterial load of $810 \mathrm{CFU} / \mathrm{mL}$ and exposed under direct sunlight. The effect of water temperature on SODIS efficiency was determined by exposing bottles on different surfaces (concrete, corrugated iron sheet (CIS) and cardboard) and by using half-surfaced black colored PET bottles and exposing them on a concrete surface.

The effect of solar intensity on SODIS was determined by exposing the bottles on three days with sky entirely covered with clouds, with few clouds and on fully sunny days, when solar radiance was recorded as $0.602 \mathrm{kWh} / \mathrm{m}^{2}, 2.77 \mathrm{kWh} / \mathrm{m}^{2}$ \& $3.99 \mathrm{kWh} / \mathrm{m}^{2}$, respectively.

SODIS bacterial inactivation efficiency was tested by adjusting turbidity of the water, water depth, solar intensity, and exposure time. This helps to identify optimum SODIS efficiency levels for direct applicability of the technology. The application of SODIS for naturally contaminated sources was further demonstrated by abstracting well water having turbidity of 13.0NTU and dissolved oxygen concentration of $3.24 \mathrm{mg} / \mathrm{L}$. By aerating the water sample, the DO was increased from $3.24 \mathrm{mg} / \mathrm{L}$ to $4.86 \mathrm{mg} / \mathrm{L}$. Possibility of microbial re-growth was determined by storing the treated water under room temperature for about four days.

\section{Analytical methods Physical analysis}

Physical parameters of water were measured following standard procedures [9] (see Table 1). Solar irradiance was calculated based on the equation: $\hat{E}^{* *} \epsilon^{*} \mathrm{As}=\mathrm{Qconv}+$ Qrad, where É = solar irradiance; $\epsilon=$ emissivity; As = surface area in contact with air; Qconv = rate of natural convection heat transfer; and Qrad = rate of radiation heat transfer [10].

\section{Microbial analysis}

Samples were taken by shaking the exposed bottles to distribute fecal coliforms evenly in the bottled water. During sampling and transportation samples were protected from direct sunlight and transported in cold box at $-8^{\circ} \mathrm{C}$ following standard methods [11]. The analysis was carried out within 6 hours of sample collection. Plate count agar was used for medium of bacterial growth and the sample was incubated at $44.5^{\circ} \mathrm{C}$ for 48 hours. Fecal coliform enumeration was done by a standard pour plate method [9]. This method was used so as to not getting running out of the water sample exposed for sunlight in frequent sampling by its advantage of using small water sample.

\section{Data analysis}

Data were analyzed using SPSS Software for Windows Version 16. Descriptive statistics were performed to summarize the data in the form of mean and standard deviation. Non-parametric statistical tests were performed to test mean difference of log inactivation of fecal coliform and rate of inactivation among different variables at confidence level of $(\alpha$-value $=0.05)$.

\section{Results}

\section{Effect of raw water turbidity on SODIS efficiency}

The highest log inactivation $(0.93 \pm 0.08)$ was obtained at turbidity value $2 \mathrm{NTU}$. On the contrary, the least log inactivation $(0.05 \pm 0.005)$ was found at turbidity $81 \mathrm{NTU}$ (Figure 1). Log inactivation results were statistically

Table 1 Physicochemical parameters and the instruments used for measuring, June, 2011, Jimma, Ethiopia

\begin{tabular}{ll}
\hline Parameters & Measuring instrument \\
\hline $\mathrm{pH}$ & Portable Wagtech $^{\oplus} 911 \mathrm{pH}$ meter \\
Turbidity & Portable Wagtech ${ }^{\circledR}$ turbidity meter \\
$\mathrm{DO}$ & Multi-parameter probe $\mathrm{HACH}^{\oplus}$ \\
Exposure time & Stopwatch \\
Water temperature & Handheld Knick Portamess \\
& thermometer \\
Sunlight intensity (irradiance) & Non-contact thermometer and black \\
& body using mathematical equation
\end{tabular}

๑: registered trademark symbol. 


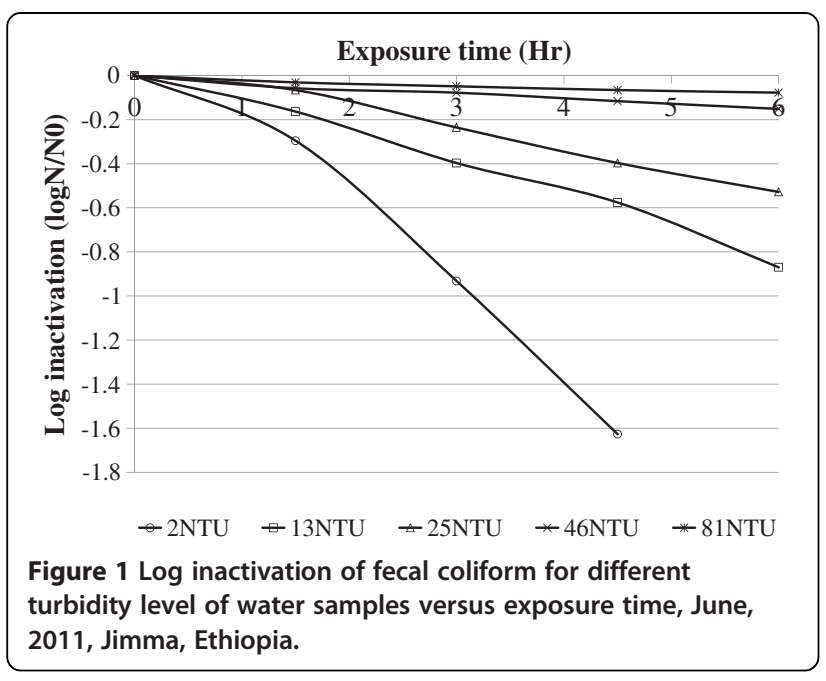

significant between the different water samples having different turbidity $(\mathrm{p}=0.009)$.

\section{Effect of water depth on efficiency of SODIS}

Highest log inactivation of fecal coliform $(2.91 \pm 0.001)$ was found on water samples having water depth of $5.5 \mathrm{~cm}$ (Figure 2). The lowest log inactivation $(0.474 \pm 0.044)$ was obtained on $10 \mathrm{~cm}$ water depth after 3 hours of exposure. Kruskal-Wallis test on log inactivation of fecal coliform showed statistically significant differences among water samples with different water depths $(\mathrm{p}=0.015)$.

\section{Effect of water temperature on SODIS}

A significantly higher rate of bacterial inactivation was found using half-surfaced black colored PET bottle in comparison to raw water samples exposed on the surface of cardboard, concrete and CIS (Figure 3).

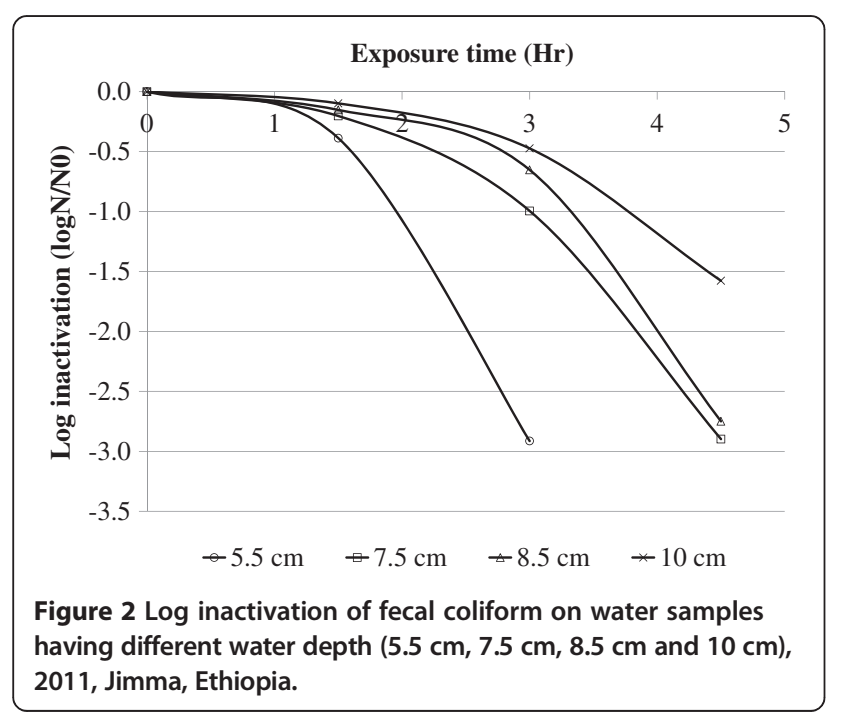

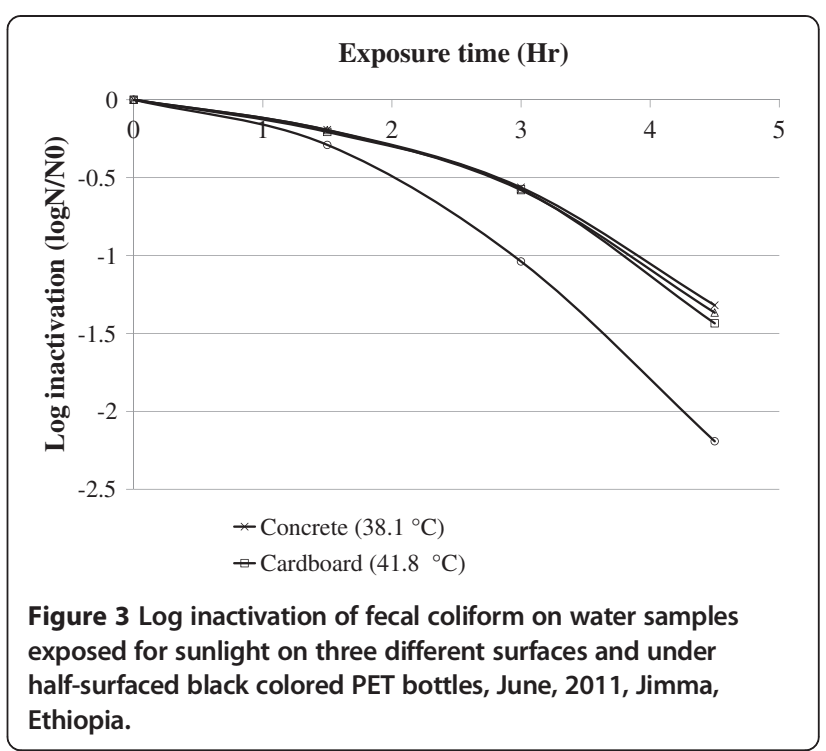

\section{Effect of solar intensity on SODIS}

Within three hours of exposure, the highest log inactivation of fecal coliform $(1.65 \pm 0.05 \mathrm{log})$ was found on water samples exposed for sunlight having a cumulative solar irradiance of $3.99 \mathrm{kWh} / \mathrm{m}$ and the lowest $\log$ inactivation $(0.2 \pm 0.01 \mathrm{log})$ and $(0.95 \pm 0.03 \mathrm{log})$ at cumulative solar irradiance of $0.6026 \mathrm{kWh} / \mathrm{m}^{2}$ and $2.77 \mathrm{kWh} / \mathrm{m}^{2}$. The mean log inactivation of fecal coliform found on the three different days was significantly different (KruskalWallis test, $\mathrm{p}=0.027$ ).

Testing the efficiency SODIS under adjusted parameters After the parameters were adjusted as described in the Methods section, SODIS efficiency was $2.554 \pm 0.093 \mathrm{log}$ inactivation after three hours of exposure under turbidity $2 \mathrm{NTU}, \mathrm{pH} 7, \mathrm{DO}$ of $6.52 \mathrm{mg} / \mathrm{L}$, half-surfaced black colored PET bottle and water depth of $10 \mathrm{~cm}$. No microbial inactivation was found in the control water samples (Figure 4). Mann-Whitney rank sum test on log inactivation of fecal coliform showed a statistically significant difference between the test and control water samples $(\mathrm{p}=0.037)$.

The rate of fecal coliform inactivation was found to be $(1.96 \pm 0.071)$ per hour (Figure 5$)$. The time taken to inactivate $99.9 \%$ of microbes $\left(t_{99.9}\right)$ was computed and showed that 3-log inactivation was achieved after $(3.7 \pm 0.12)$ hours exposure. The microbial re-growth test results showed that inactivated coliform bacteria failed to re-grow at ordinary room conditions after four days of storage in a dark place, or indicating that the inactivation process was irreversible.

\section{Application of SODIS for naturally contaminated water} The efficiency of SODIS was tested using naturally contaminated well water. The results show that within three 


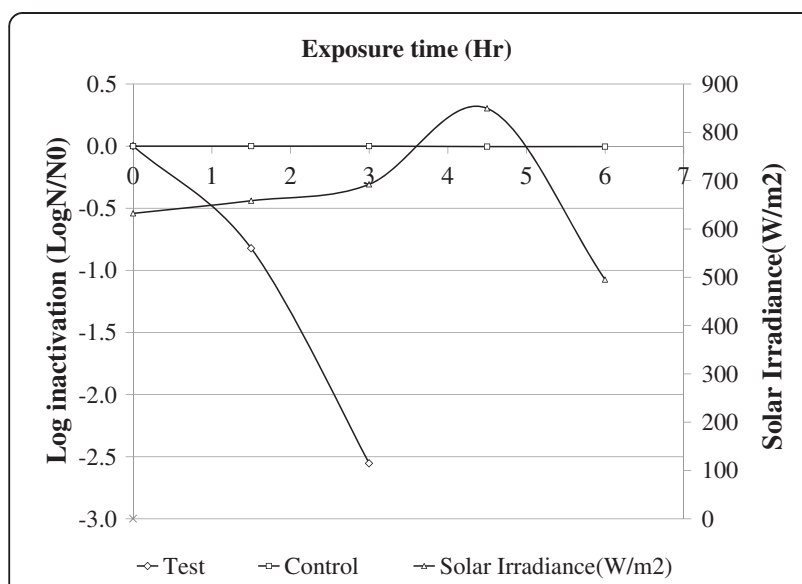

Figure 4 Log inactivation of fecal coliform on water samples exposed for sunlight under optimized conditions, June, 2011, Jimma, Ethiopia.

hours of solar exposure, $1.22 \pm 0.074 \log$ inactivation of fecal coliforms was obtained and that no fecal coliform inactivation was observed in the control water samples (Figure 6). These differences were statistically significant $(\mathrm{p}=0.046)$. The rate of microbial inactivation was found to be $(1.22 \pm 0.004)$ per hour (Figure 7$)$.

\section{Discussion}

The present study demonstrated that the applicability of low-cost household water treatment technology, using SODIS as an alternative method in the local setting. The results show $\log$ inactivation by sunlight was higher in clear raw water $(<5 \mathrm{NTU})$ and that microbial inactivation was not significantly reduced water having turbidity values greater than $20 \mathrm{NTU}$. This might be due to shielding organisms by particles [12-14] and the reduction of the amount of UV radiation that penetrates the

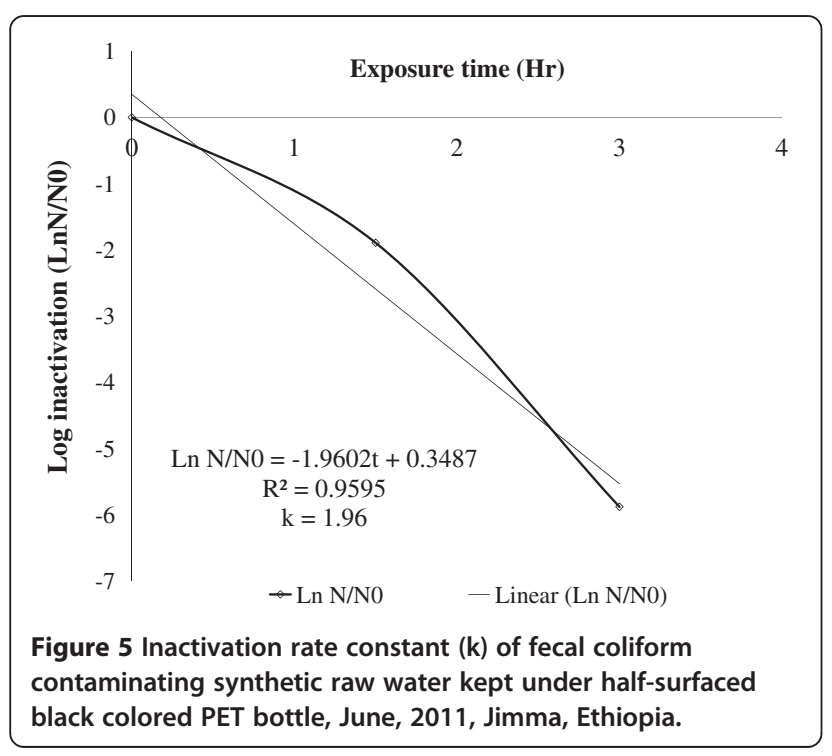

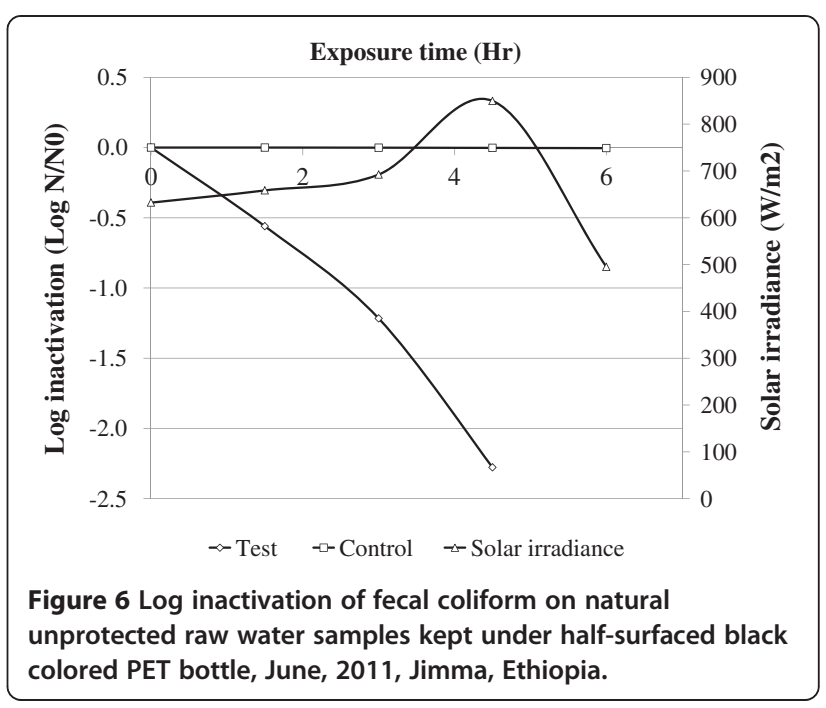

water [15]. This finding is in agreement with Wagelin et al. (1994) [16] emphasized that turbidity levels of raw water greater than $25 \mathrm{NTU}$ significantly reduce the disinfection efficiency of solar disinfection [16]. Therefore, if the turbidity of water is greater than 20NTU, the water needs to be pretreated before being exposed. Bigger particles and solids can be eliminated by storing the raw water for one day and letting the particles settle to the bottom [17]. Turbidity can also be reduced by flocculation/sedimentation using aluminium sulphate or crushed Moringa oleifera seeds, which are locally available in Ethiopia and other African countries [18].

This study demonstrated that higher bacterial log inactivation was found on water samples having shallow depth $(5.5 \mathrm{~cm})$ compared to water samples having $10 \mathrm{~cm}$ depth. This might be due to the reduction of intensity of UV radiation with increasing water depth

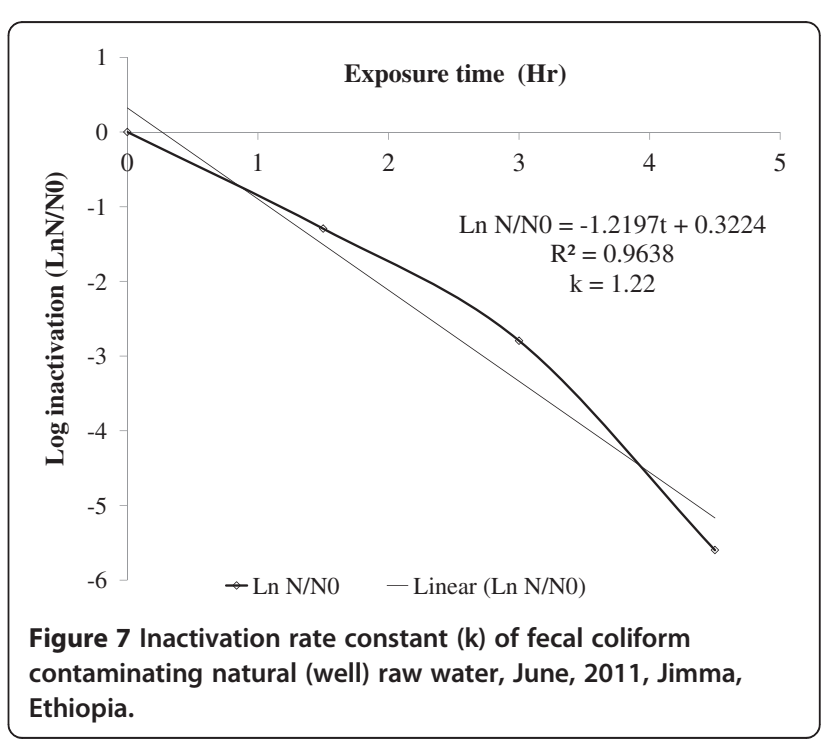


[19]. Wagelin et al. (1994) [16] reported that at a water depth of $10 \mathrm{~cm}$ and moderate turbidity level of $26 \mathrm{NTU}$, UV-A radiation is reduced to $50 \%$ [16]. Commercially produced bags made from a transparent and a black PET-sheet (SODIS-bags) with a larger area for sunlight exposure and water depth of less than $6 \mathrm{~cm}$ may be a possible solution [3].

Regarding the effect of water temperature on SODIS efficiency, bacterial inactivation was higher by a factor of 1.68 in half-surfaced black colored PET bottles than in raw water samples exposed on cardboard, concrete and CIS surfaces, This higher inactivation rate can be explained by the high $51.1^{\circ} \mathrm{C} \pm 0.17^{\circ} \mathrm{C}$ temperature of water obtained on clear sunny days. At this level of temperature synergistic effect between thermal inactivation and optical inactivation is expected $[13,16]$. This study also shows that exposing water on concrete, cardboard and CIS surfaces did not significantly affect the rate of microbial inactivation. This might be due to the fact that at the observed water temperature range $\left(38^{\circ} \mathrm{C}\right.$ to $\left.45^{\circ} \mathrm{C}\right)$, the thermal effect on bacterial inactivation is limited [13].

The present study also demonstrates complete inactivation of $E$. coli within four hours of exposure using adjusted parameters for water disinfection. The system was also found to be effective in treating natural well water. The results indicate that complete microbial inactivation within four hours of exposure time could be convenient to parts of Ethiopia with a similar climate as Jimma town, including Nazaret, Mekele, Dire Dawa, which are receiving an average of 6.00, 5.54 and $5.96 \mathrm{kWh} / \mathrm{m} 2$ solar irradiance, respectively. The microbial re-growth test revealed that inactivated coliform bacteria fail to re-grow at ordinary room conditions after four days of storage in a dark place, indicating that the inactivation process was irreversible. Berney et al. (2006) [20] has got similar result with this finding on 5 days post treatment re-growth test [20]. Irreversible inactivation is highly important in relation to storing drinking water.

The potential benefits of SODIS technology in rural areas where safe water supplies are scarce are great. Rural communities relying on boiling as a disinfectant, typically use one kilogram of wood per liter of water, which is beyond the means of most households in subSaharan Africa [21]. By applying SODIS technology, a household can conserve $3,650 \mathrm{~kg}$ of wood per year, thus contributing to reduce degradation of the forests and bushes. Another method of rendering water safe for drinking, the use of water purification tablets, is even less affordable. One tablet of Aquatab ${ }^{\circ}$, which is supposed to treat 20 liters of water, is sold for about 0.633 US dollars. One household can save \$US 116 (2204 Ethiopian Birr) per year using SODIS technology instead.

\section{Conclusions}

In conclusion, the study has revealed the possibility of disinfecting microbial contaminated water with low- or no- cost technology in Jimma town in Ethiopia. The approach may be easily adapted to Ethiopian and other sub-Saharan communities with adequate sunshine which lack potable community water supplies as a strategy to reduce water-related diseases. For wider application of SODIS in various parts of developing countries, we recommend that further studies be carried out to determine seasonal variations in the efficiency and community acceptance of this technology.

\section{Competing interests}

The authors declare that they have no competing interests.

\section{Authors' contributions}

$A D, A A$ and EA designed the study, analyzed the data, drafted the manuscript and critically reviewed the article. SM, WL, and HK drafted the manuscript and critically reviewed the article. All authors read and approved the final manuscript.

\section{Acknowledgement}

The authors are grateful to Jimma University for providing financial support. The help provided by Professor Ancha Venkata Ramayya and Mr. Yohannes Gudissa in computing solar irradiance are acknowledged.

\section{Author details}

${ }^{1}$ Department of Public Health, College of Health Science, Mekelle University, Mekelle, Ethiopia. ${ }^{2}$ Department of Environmental Health Science and Technology, College of Public Health and Medical Sciences, Jimma University, Jimma, Ethiopia. ${ }^{3}$ TREE Foundation, Texas, USA. ${ }^{4}$ Department of Epidemiology and Biostatistics, University of California, San Francisco, California, USA.

Received: 5 July 2013 Accepted: 22 December 2013

Published: 10 January 2014

\section{References}

1. Gadgil A: Drinking water in developing countries. Annu Rev Energy Environ 1998, 23(1):253-286.

2. Kumie A, Ali A: An overview of environmental health status in Ethiopia with particular emphasis to its organization, drinking water and sanitation: a literature survey. Ethiop J Health Dev 2005, 19(2):89-103.

3. Meierhofer R, Wegelin M, Torres XR: Solar water disinfection: a guide for the application of SODIS. Switzerland: EAWAG; 2002.

4. Meierhofer R: Establishing solar water disinfection as a water treatment method at household level. Madag Conserv Dev 2006, 1(1):25-30.

5. Oates PM, Shanahan P, Polz MF: Solar disinfection (SODIS): simulation of solar radiation for global assessment and application for point-of-use water treatment in Haiti. Water Res 2003, 37(1):47-54.

6. Gelover S, Go'mez LA, Reyes K, Leal MT: A practical demonstration of water disinfection using $\mathrm{TiO}_{2}$ films and sunlight. Water Res 2006, 40(17):3274-3280.

7. Sichel C, Fernándz-lbáñez P, De Cara M, Tello J: Lethal synergy of solar UV-radiation and $\mathrm{H}_{2} \mathrm{O}_{2}$ on wild Fusarium solani spores in distilled and natural well water. Water Res 2009, 43(7):1841-1850.

8. Cristinel B, Remus Z, Lucian T, Eugen A, Dumitru N: Elimination techniques of microbiological agents in water purification processes with UV radiation. J Appl Sci Environ Sanit 2011, 6(1):51-62.

9. Association APH: Standard methods for the examination of water and wastewater. Washington DC: APHA; 1998.

10. Cengel YA: Heat transfer: a practical approach. Boston: WBC MCGraw-Hill; 1998.

11. Siefring SC, Wymer LJ, Brenner KP, Dufour AP: Comparison of Enterococcus measurements in freshwater at two recreational beaches by quantitative polymerase chain reaction and membrane filter culture analysis. Water Res 2005, 39(4):559-568. 
12. Sommer B, Marino A, Solarte $Y$, Salas M, Dierolf C, Valiente C, Mora D, Rechsteiner R, Setter P, Wirojanagud W: SODIS- an emerging water treatment process. J Water SRT-Aqua 1997, 46(3):127-137.

13. McGuigan K, Joyce T, Conroy R: Solar disinfection: use of sunlight to decontaminate drinking water in developing countries. J Med Microbiol 1999, 48(9):785-787.

14. Kehoe S, Joyce T, Ibrahim P, Gillespie J, Shahar R, McGuigan K: Effect of agitation, turbidity, aluminium foil reflectors and container volume on the inactivation efficiency of batch-process solar disinfectors. Water Res 2001, 35(4):1061-1065

15. Meierhofer R, Landolt $\mathrm{G}$ : Factors supporting the sustained use of solar water disinfection-Experiences from a global promotion and dissemination programme. Desalination 2009, 248(1):144-151.

16. Wagelin M, Canonica S, Mechsner K, Pesaro F, Metzler A: Solar water disinfection: scope of the process and analysis of radiation experiments. J Water SRT-Aqua 1994, 43(3):154-169.

17. Ambelu A, Faris K: Storage and local media filters in contaminant removal. In Proceedings of WEDC conference: 1999; Addis Ababa, Ethiopia. Edited by Pickford J. UK: WEDC Loughborough; 1999:273-275.

18. Yarahmadi M, Hossieni M, Bina B, Mahmoudian M, Naimabadie A, Shahsavani A: Application of Moringa oleifera seed extract and poly aluminium chloride in water treatment. World Appl Sci J 2009, 7(8):962-967.

19. Jamal W, Siddiqui MA: Effect of water depth and still orientation on productivity for passive solar distillation. Int J Eng Res App/ 2012, 2(2):1659-1665.

20. Berney M, Weilenmann HU, Simonetti A, Egli T: Efficacy of solar disinfection of Escherichia coli, Shigella flexneri, Salmonella Typhimurium and Vibrio cholerae. J Appl Microbiol 2006, 101(4):828-836.

21. Ellis $\mathrm{K}$ : Water disinfection: a review with some consideration of the requirements of the third world. Crit Rev Environ Sci Technol 1991, 20(5-6):341-407.

doi:10.1186/2052-336X-12-25

Cite this article as: Dessie et al.: Solar disinfection: an approach for lowcost household water treatment technology in Southwestern Ethiopia. Journal of Environmental Health Sciences \& Engineering 2014 12:25.

\section{Submit your next manuscript to BioMed Central and take full advantage of:}

- Convenient online submission

- Thorough peer review

- No space constraints or color figure charges

- Immediate publication on acceptance

- Inclusion in PubMed, CAS, Scopus and Google Scholar

- Research which is freely available for redistribution 